\title{
Organism-environment interactions in a changing world: a mechanistic approach
}

\author{
John C. Wingfield $\cdot$ J. Patrick Kelley $\cdot$ Fréderic Angelier $\cdot$ Olivier Chastel $\cdot$ \\ Fumin Lei · Sharon E. Lynn · Brooks Miner · Jason E. Davis · Dongming Li · \\ Gang Wang
}

Received: 18 November 2010/Revised: 2 February 2011/Accepted: 4 February 2011/Published online: 26 February 2011

(C) The Author(s) 2011. This article is published with open access at Springerlink.com

\begin{abstract}
Understanding the interactions of an organism and its environment is essential for us to integrate ultimate and proximate causation on a global scale. Organismenvironment interaction includes all organisms including animals, plants, and non-eukaryotes, etc. because all of them are responsive to environmental change including those that are human-induced. A mechanistic approach is important for
\end{abstract}

Communicated by F. Bairlein.

J. C. Wingfield $(\bowtie) \cdot$ J. Patrick Kelley $\cdot$ F. Angelier

Department of Neurobiology, Physiology and Behavior,

University of California, Davis, CA 95616, USA

e-mail: jcwingfield@ucdavis.edu

O. Chastel

Centre d'Etudes Biologiques de Chizé, CNRS,

79360 Villiers en Bois, France

F. Lei

Institute of Zoology, Chinese Academy of Sciences, Beijing, China

S. E. Lynn

Department of Biology, College of Wooster, Wooster, OH, USA

B. Miner

Department of Biology, University of Washington, Seattle, WA 98195, USA

J. E. Davis

Department of Biology, Radford University,

310 Reed, Box 6931, Radford, VA 24142, USA

D. Li

College of Life Sciences, Hebei Normal University, 050016 Shijiazhuang, China

G. Wang

Department of Biology, University of Kentucky, Lexington, KY, USA us to understand why some organisms can cope with change and others cannot. Here, we present three examples of environments ("the three poles") that are changing rapidly and how avian species typical of these ecosystems are responding. These examples include apparently adaptive responses to change in climate (i.e. the predictable environment) in one species in which a lengthened breeding season now allows multiple breeding attempts. Why other species are unable to respond in a similar way remains unclear. A second example describes how changing weather (i.e. the unpredictable) may have disastrous results for breeding success in a species adapted to an extreme cold environment. Implications for climate change in which weather extremes will become more common again suggest a mechanistic approach will be important to understand how organisms may respond. The third example outlines a scenario in which multiple human-induced rapid changes (a combination of predictable and unpredictable such as development, habitat change, introduction of invasive species and climate change) may influence indigenous species in different ways. Organism-environment interaction is a fundamental concept that may unify ultimate and proximate causation and point the way for future investigations striving to understand coping mechanisms in a world where both predictable and unpredictable components of the environment are changing.

Keywords Stress · Seasonality · Polar region . Corticosterone

\section{Introduction}

How organisms respond to a changing environment is an emerging problem that is becoming a greater focus of basic 
research in the light of global change (reviewed in Visser 2008). Although planet Earth has undergone dramatic changes in climatic, biological and geophysical conditions, these have occurred over time spans of millions of years allowing evolution of mechanisms by which organisms respond to environmental change such as seasons, day/ night cycles, high tide/low tide, etc. (e.g., Wingfield 2008a, b). Overarching questions include: how do organisms organize their life cycles, time components of those cycles and synchronize them with other individuals? To do this, they must respond to internal cues (classical homeostasis) and external cues from both the physical environment and the social environment. Internal, external and social cues all interact with morphology, physiology and behavior in complex ways affecting evolution of mechanisms allowing an individual to cope with a changing world (e.g., Huey et al. 2003; Duckworth 2009). Taken together, these processes define the bidirectional organismenvironment interaction $(\mathrm{O}, \mathrm{E})$ that has been formalized as follows (after Lewontin 1983; Odling-Smee 1988):

$$
\begin{aligned}
\frac{\mathrm{d} O}{\mathrm{~d} t} & =f(O, E) \\
\frac{\mathrm{d} E}{\mathrm{~d} t} & =g(E, O)
\end{aligned}
$$

where Eq. 1 captures how changes in the organism (morphological, physiological and behavioral) occur over time $(\mathrm{d} O / \mathrm{d} t)$ as a function of environmental changes (e.g., daily rhythms, tidal rhythms, lunar cycles, annual cycles and seasons) as well as homeostatic changes within the organism. Equation 2 describes the feedback established in Eq. 1 and highlights how changes to selective environments $(\mathrm{d} E / \mathrm{d} t)$ can be altered by an organism's response to changes in the environment.

It is useful to pause and consider this simple coupled relationship because it addresses the origin and evolution of coping strategies, but it is also useful for considering proximate causation-the mechanisms underlying how organisms respond to external environmental cues with internal change. At this point, it is relevant to think about ways in which organism-environment interaction might work in naturalistic settings.

At a mechanistic level, for organism-environment interaction to operate an individual must first perceive the environment and thus assess changes in conditions, then transduce that information into a neural and/or hormonal response that finally regulates the morphological, physiological and behavioral responses. In general, the perception of environmental conditions involves two major processes (de Wilde 1978; Wingfield et al. 1998; Fig. 1):

1. A direct response of a cell to environmental conditions (such as temperature, osmotic change, etc.) that does
Pathways of Transduction for Proximate Information

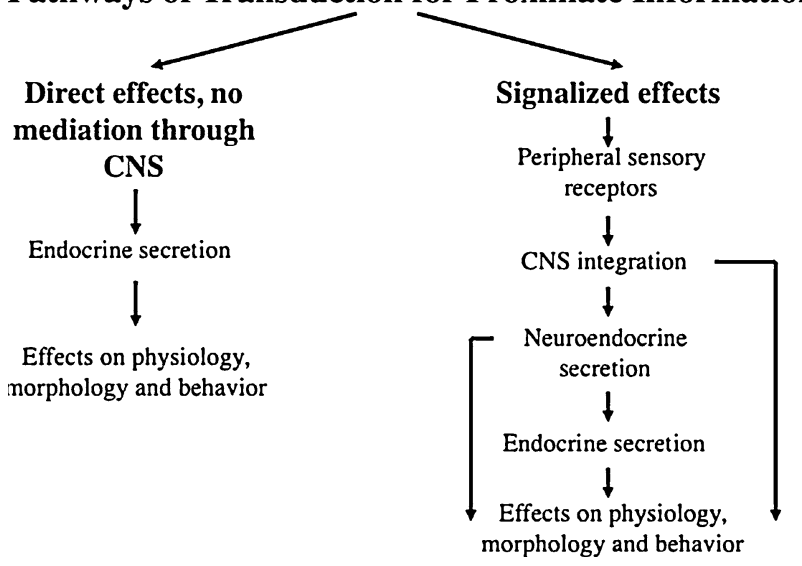

Fig. 1 Pathways by which proximate information from the environment are transduced into effects on physiology, morphology and behavior can be summarized in two major categories. Direct effects of environmental conditions can affect cells and their responses without being mediated through neural and hormonal cascades. Indirect, or signalized, effects require sensory perception, neural transduction and finally neuroendocrine and endocrine cascades. Drawn from de Wilde (1978)

not involve neural or hormonal input. Examples are response of mucosal cells in the gut to gastro-intestinal tract contents (e.g., pH), a chloride cell in the gill of a fish to osmolarity of water, etc.

2. An indirect response in which the environmental stimulus is perceived through some sensory modality, transduced through central nervous centers into neuroendocrine and endocrine cascades that regulate the response. This was termed by de Wilde (1978) a "signalized response" (Fig. 1).

Environmental cues are extremely diverse involving all aspects of daily, tidal and seasonal changes of conditions. How these cues influence organism-environment interaction can be summarized in two major groups (Fig. 2). Firstly, there is the group of those which provide predictive information to allow regulated changes in morphology physiology and behavior in anticipation of future events such as breeding, migration, molt, etc. For example, environmental cues such as changing daylength can be used to initiate gonadal maturation so that the individual is able to begin breeding once environmental conditions become conducive to successful reproduction. This type of cue is called initial predictive (e.g., Wingfield 2008a, b; Wingfield and Kenagy 1991). Then, local predictive cues such as temperature, rainfall, and food availability regulate adjustment of onset of breeding to the immediate environmental conditions. Secondly, an individual must respond to unpredictable environmental perturbations that require physiological and behavioral responses during and after the event (Fig. 2). This may involve triggering an 


\section{Environmental change}

\begin{tabular}{|c|c|}
\hline Predictable & Unpredictable \\
\hline & $\begin{array}{l}\text { Storms, weather, drought } \\
\text { food availability }\end{array}$ \\
\hline Day/night rhythms & Social status change \\
\hline Tidal rhythms & Predators \\
\hline Lunar cycles & Injury and infection \\
\hline Seasons & Human disturbance \\
\hline Rainy season/dry season & Pollution \\
\hline & $\begin{array}{l}\text { Invasive species } \\
\text { Global climate change }\end{array}$ \\
\hline $\begin{array}{l}\text { Regulated changes of } \\
\text { morphology physiology and } \\
\text { behavior in anticipation of the } \\
\text { event }\end{array}$ & $\begin{array}{l}\text { Rapid facultative changes of } \\
\text { behavior and physiology during } \\
\text { and after the event }\end{array}$ \\
\hline
\end{tabular}

Fig. 2 Environmental change (and the information that can be obtained from that change) can be summarized in two major ways. Firstly, predictable environmental changes such as light/dark cycles of day and night, tidal rhythms, seasons, allow an individual to anticipate future events such as breeding seasons and prepare morphologically, physiologically and behaviorally. In contrast, unpredictable perturbations of the environment must be dealt with on a facultative basis during and after the event. The mechanisms underlying these two types of organism-environment interaction are fundamentally different and highly pertinent to current problems of how organisms respond to global change. From Wingfield (2008a)

emergency life history stage resulting in abandonment of the life history stage of the predictable life cycle (e.g., breeding) and survival of the perturbation. Once the perturbation passes, then the life history stage relevant to that time of year will be assumed (e.g., Wingfield et al. 1998; Wingfield and Ramenofsky 1997; Wingfield 2003).

Using environmental cues as predictive information to prepare for different life history events, the immediate response to unpredictable perturbations involves fundamentally different processes underlying organism-environment interaction with profound implications for mechanisms of perception, transduction and responses. Much more basic research is needed to understand the mechanisms by which organism-environment interaction works, but what has been lacking is a theoretical framework relevant for at least vertebrates in diverse ecosystems globally (e.g., Wingfield 2005, 2008a, b; McNamara and Houston 2009). This is even more urgent at present because of human-induced rapid environmental change.

It is very well known that phenological processes such as plant growth, emergence of arthropods and migrations and breeding seasons of many vertebrates are changing owing to human-induced global effects (Thomas and Lennon 1999; Pulido et al. 2001; Both and Visser 2001; Walther et al. 2002; Visser and Holleman 2001; Lehikoinen et al. 2006; Barbraud and Weimerskirch 2006; Møller et al. 2008; Moe et al. 2009). Responses of species and populations to these changes are complex and difficult to predict. Furthermore, those species that appear unable to adjust to global change are declining (Møller et al. 2008), emphasizing why we need to better understand organismenvironment interaction. These effects are ongoing and the outcome for biodiversity, at the population level and for coping mechanisms, remains unknown. Biological trends worldwide, including polar regions, are matching climate change predictions (Parmesan and Yohe 2003). Moreover, behavioral patterns of individuals that change with season and social status may also be profoundly affected by changing environments, although exactly why and how remains unclear. However, why some avian species, for example, are able to adjust to such changes but others are not remains an enigma (e.g., Wingfield 2008a). In the latter case, food available for feeding young (such as invertebrates) has been changing (generally occurring earlier), but reproductive development and onset of breeding has not adjusted resulting in a mismatch of young in the nest and peak food availability (e.g., Visser et al. 1998). Such mismatches of organism-environment interaction will potentially result in greatly reduced reproductive success and population declines.

Some predicted outcomes of global change (Travis 2003) on organism-environment interaction and the life cycles of organisms include:

1. Life history stages such as breeding are occurring earlier and later (longer duration), but what consequences this has for the timing and duration of other life history stages such as migrations, molts, etc. remains largely unknown (Wingfield 2008a).

2. Increased extremes of weather are disrupting many life history stages.

Populations are changing their distribution of both breeding and non-breeding ranges, migration stopover sites, etc.

3. Increasing competition with other species not encountered before either as invasive species introduced by humans, or as new species contacted through changed geographical distribution.

4. Changes in predator density, encounters with new predators as ranges change (of both predators and prey).

5. New pathogens may be encountered either introduced by invasive species or from expanding ranges.

6. Human disturbance through urbanization, exploitation of resources, habitat reduction, pollution and even recreation activities (e.g., Nisbet 2000; Walker et al. 2005) increasingly changes organism-environment interaction in ways that are usually detrimental.

One thing that is clear from the predicted outcomes of global changed outlined above is that although some organisms are able to adjust and even thrive, many cannot and their populations decline (Møller et al. 2008). 
A mechanistic approach to organism-environment interaction is clearly needed to tease apart the reasons why some species may cope with global change and others may not. Here, we present three examples that underscore what we know, and equally importantly, what we need to know to understand coping strategies. We focus on three examples from polar regions because these are generally changing the most rapidly and intensely (Chapin et al. 1992), although changes in the tropics have had the greatest effects on biodiversity, possibly because tropical organisms may be less flexible in adjusting to environmental change (e.g., Huey et al. 2009; Dillon et al. 2010). The arctic examples below cover changes in phenology and seasonal breeding, coping mechanisms in the face of severe storms, and a combination of changing phenology and potentially catastrophic human-induced rapid environmental change.

\section{Multiple brooding in an arctic songbird}

The Snow Bunting, Plectrophenax nivalis, is a holoarctic, high-latitude breeding songbird that we have studied intensively at Barrow, Alaska $\left(71^{\circ} \mathrm{N}\right.$; e.g., Wingfield et al. 1994; Romero et al. 1998a, b; Lynn et al. 2005). It is a socially monogamous species utilizing cavities in rocks, buildings, etc. to place the nests (Tinbergen 1939; Lyon and Montgomerie 1995; Fig. 3). In the higher Arctic regions, the breeding season is brief such that it is mostly, if not exclusively, single-brooded, at least in North America (Lyon and Montgomerie 1985, 1995: Hoset et al. 2004), Second broods have also been recorded in Greenland (Tinbergen 1939), in the high Arctic island of Svalbard (circa $76-80^{\circ} \mathrm{N}$ ) probably because the warming effect of the Gulf Stream influences the length of the summer season even at this high latitude, and at lower latitudes such as northern Scotland (Smith and Marquiss 1995). During the breeding season of 2002 at Barrow, the earliest snow melt on record to that date was recorded, essentially prolonging the potential breeding season. Indeed, snow melt dates have been occurring earlier over at least the past 20 years (Stone et al. 2001, 2002). Of about 35 nesting females (all color-banded for individual identification), we confirmed (B. Miner and S.E. Lynn) that 5 (14\%) initiated a second brood after successfully raising the first brood. We also observed 3 other late nests of females with unknown histories. These late season nests hatched between July 10 and July 19, and fledging dates ranged between July 25 and August 1. Post-nuptial (pre-basic) molt begins in July (Lyon and Montgomerie 1995) suggesting that double-brooding in this species was associated with an unusually early spring rather than delaying termination of the breeding season. Because Snow Buntings readily use nest boxes and cavities, etc., in buildings (Fig. 3), we feel that early breeding is not constrained by
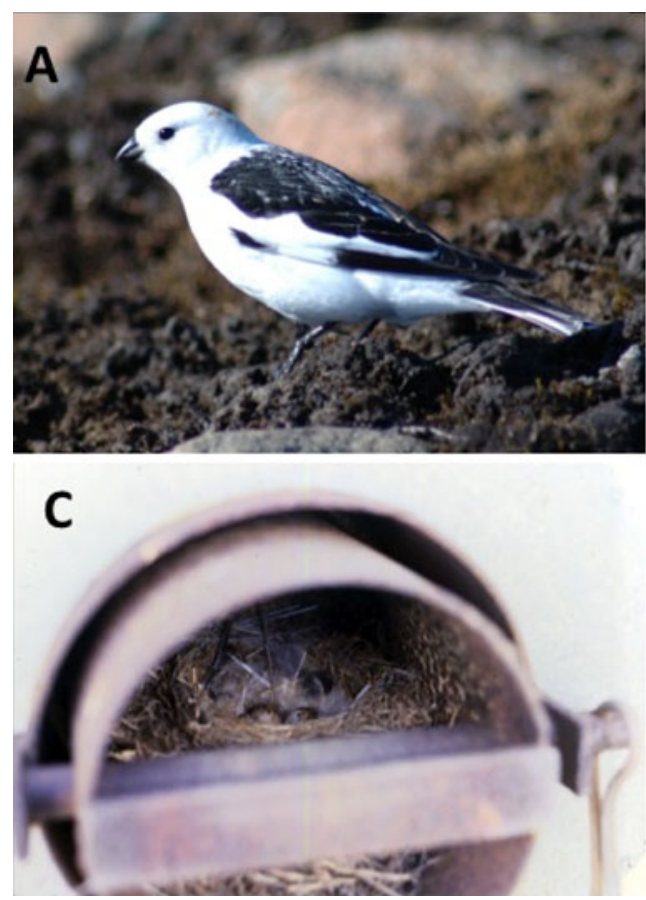

Fig. 3 Snow Buntings, Plectrophenax nivalis (a), arrive in April and May when snow cover (b) may still be $100 \%$ and frequently covering natural nest sites. Because Snow Buntings breeding at Barrow, Alaska, readily utilize nest sites of human origin such as nest boxes,

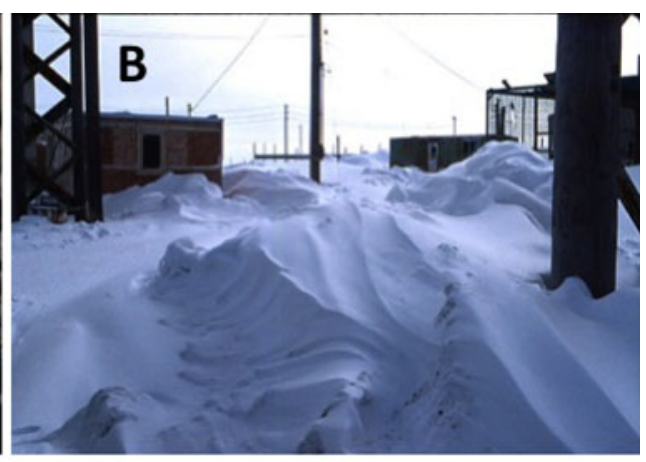

D

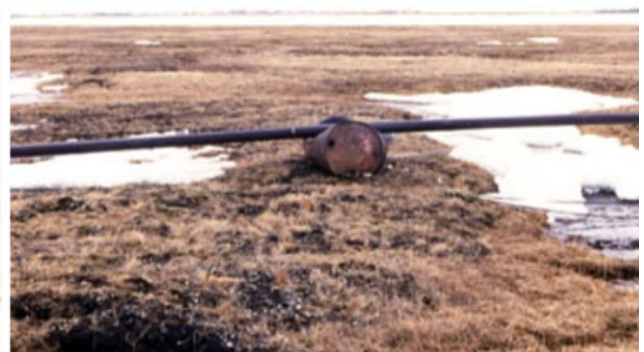

cavities in buildings (c), discarded equipment and even old oil barrels (d), they are not constrained by waiting for nest sites to be become snow-free allowing them to breed early if food resources permit. All photographs by Wingfield 
nest site availability (covered by snow early) but more by access to appropriate food resources for raising young.

Gonadal development prior to onset of nesting is probably regulated by increasing day length in spring as it is in many other mid- to high-latitude breeding species (e.g., Dawson et al. 2001). However, because the annual change in daylength is invariable from year to year, any adjustments in onset of nesting must be triggered by non-photic cues such as temperature (Wingfield and Kenagy 1991; Wingfield et al. 1992; Wingfield and Farner 1993). Effects of temperature on photoperiodically-induced gonadal growth provide some support for this hypothesis because higher ambient temperatures speed up photoperiodicallyinduced gonadal growth and may even trigger onset of nesting in some species (see Wingfield and Kenagy 1991; Wingfield et al. 1996, 1997, 2003; Dawson 2005: Silverin et al. 2008). Moreover, lower temperatures slowed down gonadal growth but also prolonged the period with mature gonads and delayed termination of the breeding season, the opposite of what we would have predicted. Curiously, higher latitude breeding species appear to be more resistant to effects of temperature on photoperiodically-induced gonadal growth, also contra what we have observed in Snow Buntings at Barrow (Wingfield et al. 1997, 2003; Dawson 2005; Silverin et al. 2008). Clearly, much more basic research is needed to understand how local predictive cues associated with early spring (or late) and onset of nesting regulate reproductive function. This is particularly pertinent to effects of global climate change.

\section{Effects of extreme weather on an Antarctic seabird}

Seabirds breeding on or near the Antarctic continent frequently must endure extreme weather including low temperatures, high winds and snow (Moss and deLeiris 1988). Most appear to cope with extreme weather unless ice conditions are affected reducing access to food (e.g., Cockrem et al. 2006). The Snow Petrel, Pagodroma nivea (Fig. 4a), lives year round in the pack ice often breeding in colonies surrounded by ice fields. They are long-lived birds with a very low fecundity (average adult life expectancy is 30 years and only one egg is laid per season, with no replacement clutch in case of failure). Sexual maturity is acquired on average at 10 years of age and birds breed annually, although a significant proportion of birds skip breeding each year (Chastel et al. 1993). Interestingly, older birds do appear to be better at raising young (Angelier et al. 2007; Berman et al. 2009) and this agespecific pattern can be related to a higher sensitivity to stress in young birds than in old birds. Thus, young Snow Petrels show an important increase in corticosterone levels
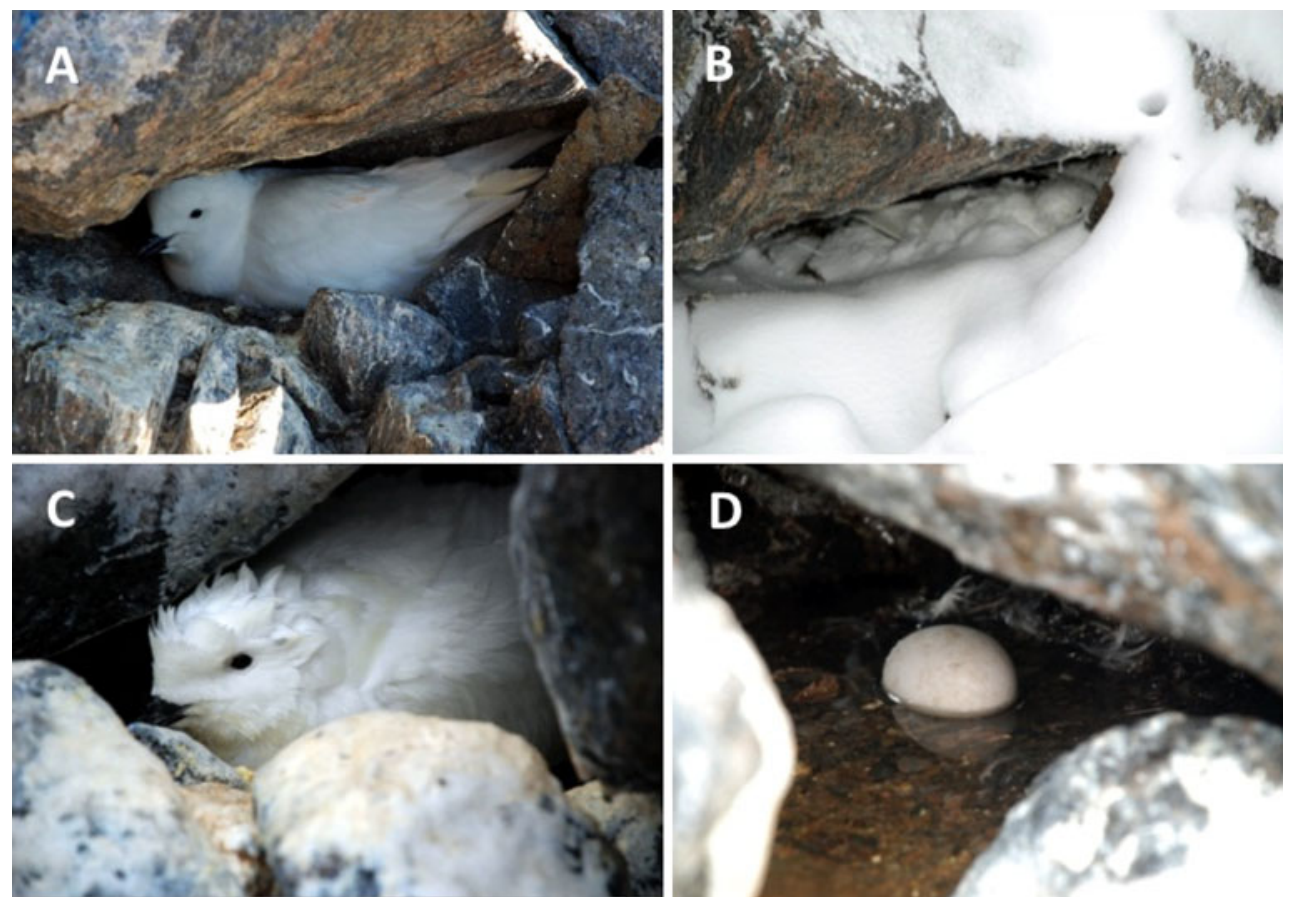

Fig. 4 The Snow Petrel, Pagodroma nivea, breeds alongside and beneath boulders in loose colonies at the French Polar Institute station at Dumont d'Urville, east Antarctica (a); snow storms driven by high winds can occur at any time during the breeding season and may virtually bury an incubating individual (b). These birds continue to incubate eggs or brood chicks with no problem but in January 2010 temperatures increased to record highs. Precipitation turned to rain and snow melted drenching incubating adults (c). Running water also flushed eggs (and chicks) out of nests (d) resulting in nest failure. All photographs by Wingfield 
in response to acute stress (tending to deter onset of breeding or promote abandonment of a nest) and a large decrease in prolactin levels (which tends to inhibit parental care thus promoting abandonment of the nest; Angelier et al. 2007, 2009; Goutte et al. 2010). These data suggest that despite breeding in a severe environment, acute stress has the potential to disrupt breeding in this species, especially in sensitive young individuals.

In general, high winds and snow per se may not constitute severe conditions for Snow Petrels (Fig. 4b) unless food availability is also affected. In January 2010 at the French Polar Institute in Dumont D'Urville (66 $40^{\circ} \mathrm{S}$, $\left.140^{\circ} 01^{\prime} \mathrm{E}\right)$, east Antarctica, several days of high winds and snow appeared to have a negligible effect on breeding Snow Petrels (Fig. 4b). However, on the fourth day of the storm, temperatures soared to record highs $\left(7.7^{\circ} \mathrm{C}\right.$ on 23 January) and snow turned to rain. Accumulated snow also melted rapidly resulting in torrents of water passing through nest sites and washing out eggs and newly hatched young (F. Angelier and J.C. Wingfield, unpublished observations; Fig. 4c, d). Curiously, it appears that warmer temperatures and potentially destructive effects of flowing water may be more of a problem than snow and ice for this species (Chastel et al. 1993). So, while choosing nest sites sheltered from snow or ice positively alters the petrel's selective environment, that same decision may create an environment that is detrimental in a different context (flooding). Although the link between the stress response and age in Snow Petrels with the snow melt/rain effect on breeding success remains to be clarified, we can hypothesize that (1) the stress response is probably linked to a decision of parents to give up breeding, and (2) snow melt and rainfall is an environmental event that cause breeding failure. Clarification of these points will be essential to interpret possible mechanisms by which organisms in general cope with unprecedented global change.

Global climate change predicts that major swings in intensity, frequency and duration of storms will increase in the near future often accompanied by new record high and/ or low temperatures (Bolger et al. 2005). Climate change in Antarctica will include not only increases in temperature but also increased precipitation (Bracegirdle et al. 2008), increasing the possibility that flowing water during the breeding season may pose a major threat to reproductive success of some Antarctic seabirds. It remains to be seen whether birds such as the Snow Petrel, and other organisms, will be able to withstand new extremes of weather outside their ancestral norms. Field work focusing facultatively on the responses of organisms to storms and other perturbation events are essential before we can begin to understand the mechanisms underlying coping with an unpredictable environment, and how well a population may be able to survive.

\section{Coping with multiple aspects of global change in songbirds at the "third pole"}

The vast region of the Tibetan Plateau (Qinghai-Xizang Plateau) of central Asia shows many similarities to the Arctic and Antarctic-hence the term "third pole". High altitude means low temperatures similar to those of the Arctic and Antarctic, including permafrost in some locations (Zheng and Li 1999; Richardson et al. 2003). High altitude at lower latitude also means longer nights during the summer (meaning that frosts during summer are common) in addition to the added challenge of relatively low partial pressure of oxygen and low humidity (Zheng and Li 1999). For these reasons, conditions at this third pole may be potentially even more severe than in the Arctic and Antarctic (e.g., Richardson et al. 2003).

The extensive high altitude plateau of the Tibet region is particularly sensitive to global warming in combination with other changes associated with human activity (Liu and Chen 2000). With continued global warming, permafrost will likely disappear or be greatly reduced on the Tibetan Plateau within the next 200 years resulting in major changes in erosion, etc. (Wang and French 2006; Li et al. 1996). The lower altitudinal limit of permafrost has risen $50-80 \mathrm{~m}$ in the south of the region and by $25 \mathrm{~m}$ in the north over the last 20 years (Cheng and Wu 2007). Furthermore, the active layer (i.e., the layer that melts each summer) has deepened to $0.5 \mathrm{~m}$. Degradation of permafrost can also lower water tables adding to changes precipitated by global warming (Wu and Liu 2004; Cheng and $\mathrm{Wu}$ 2007). Meteorological stations on the Tibetan Plateau during the period 1971-2000 showed that the main trends of climate change are temperature rises and precipitation increases. Additionally, there is a potential decrease of evaporation and transpiration resulting in most areas becoming more humid (Wu et al. 2005).

A very common mammal species on the grasslands of the Tibetan Plateau is the Plateau Pika, Ochotona curzoniae (Fig. 5a). It digs extensive and interconnected burrows that are used by several other vertebrates on the Plateau for shelter at night and during severe weather, and for breeding (such as nesting White-rumped, Onychostruthus taczanowskii, Fig. 5b, and Rufous-necked Snowfinches, Pyrgilauda ruficollis). In this regard, the Pika is a keystone species promoting biodiversity on the plateau (Smith and Foggin 1999). However, because the Pika can reach high densities, especially during summer, it is often regarded by humans as a pest and detrimental to grazing of domestic animals such as yaks, sheep and horses. For this reasonm Pika poisoning programs have been introduced in some areas resulting in complete eradication of local populations. Absence of Pikas means that the burrow systems disintegrate and species dependent upon them disappear. 

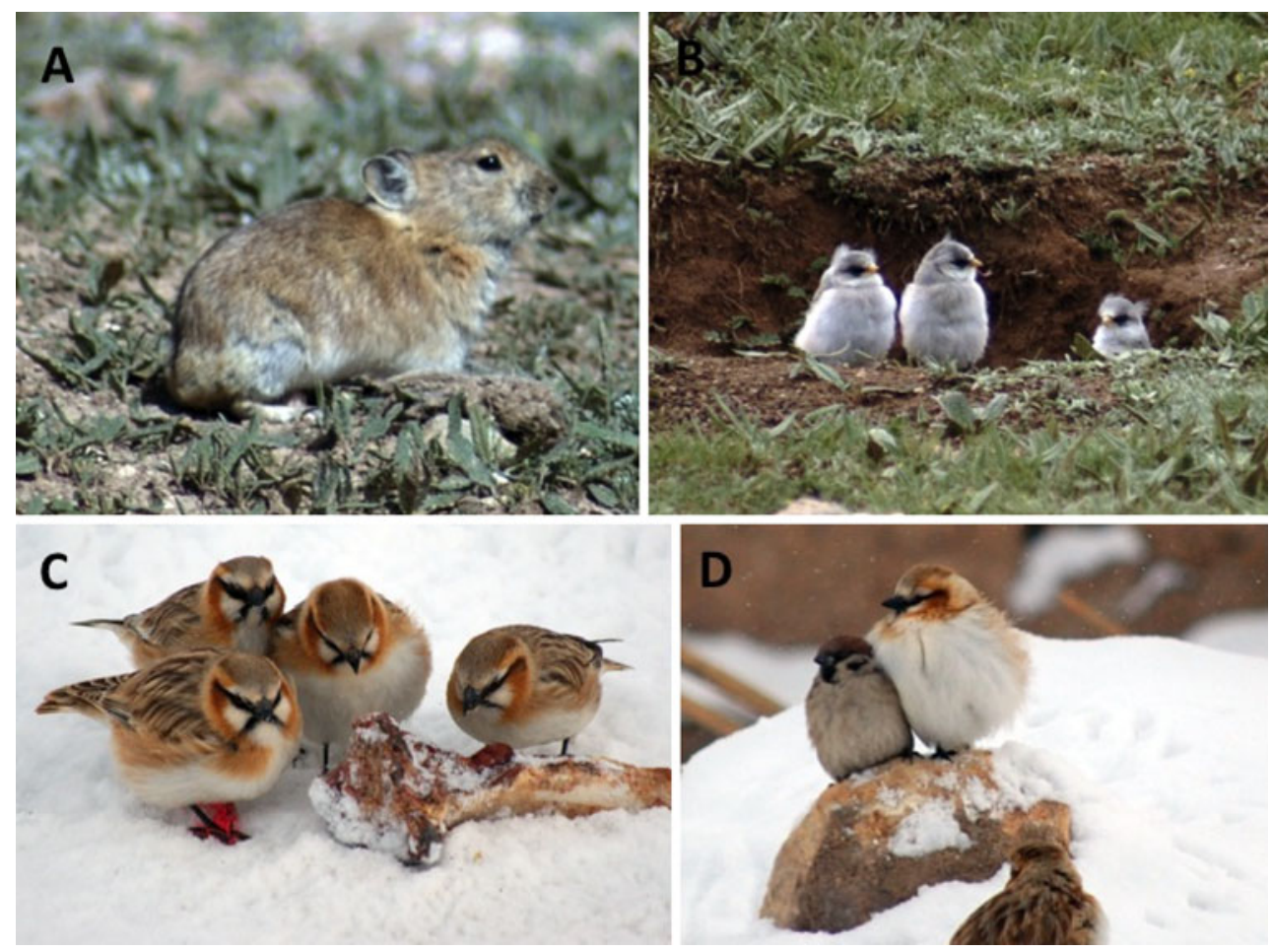

Fig. 5 The Plateau Pika, Ochotona curzoniae (a), excavates extensive burrow systems that provide shelter, nest sites, etc. for other species. For example, White-rumped Snowfinches, Onychostruthus taczanowskii, use Pika burrows as nest sites (b, three fledgling Whiterumped Snowfinches emerge from the nest burrow). Rufous-necked Snowfinches, Pyrgilauda ruficollis, eating human foods (c); note also

Furthermore, the grasslands revert to shrub, reducing foraging even more than when Pikas were present (Smith and Foggin 1999). This type of human intervention in an ecosystem clearly has dramatic effects on many species, although it is not the sole source of human environmental modification having an impact on native birds. Bird species richness and overall avian abundance were greater on sites that had not been poisoned compared with poisoned sites. Thus, Pikas were considered as a keystone species in maintaining the sensitive alpine grassland ecosystem of the Plateau (Lai and Smith 2003).

Development of the Tibetan Plateau has also increased dramatically in the past 20 years with new settlements appearing as roads and railways are built further into the grasslands, and the population of existing settlements expanding rapidly. This in itself represents human-induced rapid change through development, but it also means introduction of invasive species (Fig. 3d) that not only compete for food and other resources but also transmit exotic diseases. Close proximity of one common species, the Eurasian Tree Sparrow, Passer montanus, that has invaded new settlements, with Rufous-necked Snow Finches represents an ideal scenario for transmission of diseases (Fig. 3d). Curiously, the White-rumped Snowfinch the red plastic string (human trash) wrapped around the foot of the bird at left front. Invasive species such as the Eurasian Tree Sparrow, Passer montanus, may directly contact native species such as the Rufous-necked Snowfinch (d). An ideal scenario for transmission of exotic diseases brought in by the sparrow. Photographs by Wingfield $(\mathbf{a}, \mathbf{b})$ and Gang Wang $(\mathbf{c}, \mathbf{d})$

does not associate with invasive species and are extremely aggressive among themselves and toward other songbird species. Furthermore, they shun newly developed human habitations, unlike the Rufous-necked Snowfinch. Thus, two relatively closely related endemics of the Tibetan Plateau may experience local environmental change very differently.

Another consequence of human disturbance on the plateau is the appearance of open garbage disposal sites at new human developments. This in turn exposes some local species to endocrine disrupters in garbage as well as providing access to human foods and waste disposed in open garbage piles. Rufous-necked Snowfinches readily take to eating human-derived foods (Fig. 3c), especially in winter, whereas White-rumped Snowfinches do not. Waste disposal sites may provide an important food resource for invasive and exploratory native species, encouraging social interaction and group formation, as well as providing food caches that may be of benefit during inclement weather. Another important consequence of this observation stems from recent evidence suggesting that additives to human foods can have complex epigenetic effects on offspring that can be transmitted over several generations. For example, an endocrine disrupter, 
bisphenol A, can interfere with DNA methylation patterns, and thus gene transcription, altering the phenotypes of offspring in deleterious ways (Dolinoy et al. 2007). However, food additives such as folic acid can ameliorate DNA methylation effects of Bisphenol A (Dolinoy et al. 2007). On the other hand, folic acid may alter DNA methylation patterns in human fetuses resulting in deleterious effects on growth and development (SteegersTheunissen et al. 2009). The implications of these epigenetic effects from endocrine disrupters and from the dietary additives organisms may be exposed to in discarded human foods are likely enormous and remain essentially unknown.

The two species of Snowfinches we have studied on the Tibetan Plateau (e.g., Richardson et al. 2003) represent an ideal model system to assess the cumulative effects of global climate change, human, disturbance, changed habitat and food sources and invasive species.

The adrenocortical responses to acute stress in Eurasian Tree Sparrows are seasonally modulated in a manner similar to Snowfinches ( $\mathrm{Li}$ et al. 2008). Although this may allow invasive species to adapt to the extreme environment, compared to Snowfinches, Eurasian Tree Sparrows have the advantage of being more flexible as to nest building sites and finding refuges during bad weather as long as there are human activities. Eurasian Tree Sparrow populations also maintain a longer and less synchronous breeding period on the Tibetan Plateau than do the native Snowfinches. More interestingly, invasion by Eurasian Tree Sparrows may have different effects on White-rumped Snowfinches versus Rufous-necked Snowfinches. During the breeding season, Eurasian Tree Sparrows are always in small villages and cities, while both Snowfinches are outside villages most of time. During this period, there is not much interaction between Eurasian Tree Sparrows and snowfinches. However, in the winter, some Rufous-necked and White-rumped Snowfinches are still outside villages, while many Rufous-necked Snowfinches spend large portions of the day feeding in the villages sharing the feeding sites with Eurasian Tree Sparrows. As such, there may be potential competition between Eurasian Tree Sparrows and Rufous-necked Snowfinches for food resources in winter (Fig. 3). Global environmental change (including change of human activity) may affect these birds differently. Invasive Eurasian Tree Sparrows would seem to be more resistant to environmental change as long as they are in close contact with human-modified environments. Rufous-necked Snowfinches are less resistant compared to Eurasian Tree Sparrow because they are restricted by their nesting sites and refuges during extreme weather, although they do take advantage of human habitations (especially during extreme weather in winter). But Rufous-necked
Snowfinches are more resistant to the environmental change and human disturbance compared to White-rumped Snowfinches, especially in winter because Whiterumped Snowfinches are found exclusively in rural areas and do not seem to benefit directly from human-derived food sources.

It is important to know which species might be affected most by invasive species and human disturbance and which may not, as well as which native species have the most capability to adapt to human-induced environmental modification. The flexibility and environmental dependence of species in such extreme habitats may in large part be related to stress and aggressive response patterns and reproductive requirements.

\section{Conclusions}

Organism-environment interaction represents a biological phenomenon that integrates ultimate and proximate causation on a global scale. Furthermore, it includes all organisms including plants and non-eukaryotes because all organisms are being affected by human-induced rapid environmental change. A mechanistic approach will be critical to understand why some organisms can cope with change and others cannot. New opportunities are developing to study organism-environment interaction. Improved methods for gene profiling mean it is more efficient and cheaper to sequence transcriptomes in tissues from individuals in different habitats, social conditions, etc. Emerging techniques in proteomics and biochemical aspects (e.g., metabolome) allow additional perspectives on organism-environment interaction downstream of gene expression. Recent investigations on maternal effects (and paternal) reveal highly significant effects on phenotypes of offspring that can be passed on to other generations. Effects of diet and endocrine disrupters on gene methylation patterns become pertinent here. There is also a great need for mathematical models to provide a framework at the mechanistic levels underlying organism-environment interaction. Long-term studies are essential to assess global change, and these datasets allow integration and unique collaborations across disciplines. International collaborations will allow investigations of common species in diverse habitats with inter-continental perspectives. This is a time of considerable concern for biodiversity on Earth, but it is also a turning point for integrative biology to bridge rifts between biological disciplines such as organismal and cell and molecular biology that have grown even wider over the past few decades. Organism-environment interaction is a concept that has the potential to unify biological concepts in a way unprecedented only a few years ago. 
Acknowledgments J.C.W. is grateful to the National Science Foundation for a series of grants that have supported much of the research and ideas discussed in this manuscript. The most current grant is IOS-0750540. He also acknowledges support from the Endowed Chair in Physiology, University of California, Davis. Many thanks also to the French Polar Institute (IPEV, Prog. 109 to H. Weimerskirch) and the Chinese Academy of Sciences. J.C.W., S.E.L. and B.M. thank the Ukpeagvik Corporation, Barrow, Alaska, and Robert Suydam for permission and guidance to conduct research in Barrow. Thanks also to Matt Seidensticker for assistance with field work. F. Angelier is supported by a Marie Curie Fellowship (Polarclimstress).

Open Access This article is distributed under the terms of the Creative Commons Attribution Noncommercial License which permits any noncommercial use, distribution, and reproduction in any medium, provided the original author(s) and source are credited.

\section{References}

Angelier F, Moe B, Weimerskirch H, Chastel O (2007) Age-specific reproductive success in a long-lived bird: do older parents resist stress better? J Anim Ecol 76:1181-1191

Angelier F, Moe B, Blanc S, Chastel O (2009) What factors drive prolactin and corticosterone responses to stress in a long-lived bird species (snow petrel, Pagodroma nivea)? Physiol Biochem Zool 82:590-602

Barbraud C, Weimerskirch H (2006) Antarctic birds breed later in response to climate change. Proc Nat Acad Sci USA 103:62486251

Berman M, Aillard JM, Weimerskirch H (2009) Contrasted patterns of age-specific reproduction in long-lived birds. Proc $\mathrm{R}$ Soc Lond B 276:375-382

Bolger DT, Patten MA, Bostock DC (2005) Avian reproductive failure in response to an extreme climate event. Oecologia 142:398-406

Both C, Visser ME (2001) Adjustment of climate change is constrained by arrival date in a long-distance migrant bird. Nature 411:296-298

Bracegirdle TJ, Connolley WM, Turner J (2008) Antarctic climate change over the twenty first century. J Geophys Res 113. doi: 10.1029/2007JD008933

Chapin FS III, Jefferies RL, Reynolds JF, Shaver GR, Svoboda J (eds) (1992) Arctic ecosystems in a changing climate. Academic, San Diego

Chastel O, Weimerskirch H, Jouventin P (1993) High annual variability in reproductive success and survival of an Antarctic seabird, the snow petrel, Pagodroma nivea. Oecologia 94:278-285

Cheng G, Wu T (2007) Responses of permafrost to climate change and their environmental significance, Quinghai-Tibet Plateau. J Geophys Res 112. doi:10.1029/2006JF000631

Cockrem JF, Potter MA, Candy EJ (2006) Corticosterone in relation to body mass in Adelie penguins (Pygoscelis adeliae) affected by unusual sea ice conditions at Ross Island, Antarctica. Gen Comp Endocrinol 149:244-252

Dawson A (2005) The effect of temperature on photoperiodically regulated gonadal maturation, regression and moult in starlingspotential consequences of climate change. Funct Ecol 19:995-1000

Dawson A, King VM, Bentley GE, Ball GF (2001) Photoperiodic control of seasonality in birds. J Biol Rhythms 16:365-380

de Wilde J (1978) Seasonal states and endocrine levels in insects. In: Assenmacher I, Farner DS (eds) Environmental endocrinology. Springer, Berlin, pp 10-19
Dillon ME, Wang G, Huey RB (2010) Global metabolic impacts of recent climate warming. Nature 467:704-706

Dolinoy DC, Huang D, Jirtle RL (2007) Maternal nutrient supplementation counteracts bisphenol A-induced DNA hypomethylation in early development. Proc Natl Acad Sci USA 104:13056-13061

Duckworth RA (2009) The role of behavior in evolution: a search for mechanism. Evol Ecol 23:513-531

Goutte A, Antoine E, Weimerskirch H, Chastel O (2010) Age and the timing of breeding in a long-lived bird: a role for stress hormones? Funct Ecol (in press)

Hoset KS, Espmark Y, Moksnes A, Haugan T, Ingebrigtsen M, Lier M (2004) Effe cts of ambient temperature on food provisioning and reproductive success in snow buntings, Plectrophenax nivalis, in the High Arctic. Ardea 92:239-246

Huey RB, Hertz PE, Sinervo B (2003) Behavioral drive versus behavioral inertia in evolution: a null model approach. Am Nat 161:357-366

Huey RB, Deutsch CA, Tewksbury JJ, Vitt LJ, Hertz PE, Álvarez Pérez HJ, Garland T (2009) Why tropical forest lizards are vulnerable to climate warming. Proc $\mathrm{R}$ Soc Lond $\mathrm{B}$ 276:1939-1948

Lai CH, Smith AT (2003) Keystone status of plateau pikas (Ochotona curzonaie): effect of control on biodiversity of native birds. Biodivers Conserv 12:1901-1912

Lehikoinen E, Sparks TH, Zalakevicius M (2006) Arrival and departure dates. In: Møller AP, Fiedler W, Berthold P (eds) Birds and climate change. Elsevier, Amsterdam, pp 1-31

Lewontin RC (1983) The organism as the subject and object of evolution. Scientia 118:63-82

Li S, Cheng G, Guo D (1996) The future thermal regime of numerical simulating permafrost on Qinghai-Xizang (Tibet) Plateau, China, under climate warming. Sci China 39:436-551

Li D, Wang G, Wingfield JC, Zhang Z, Ding C, Lei F (2008) Seasonal changes in adrenocortical responses to acute stress in Eurasian tree sparrow (Passer montanus) on the Tibetan Plateau: comparison with house sparrow ( $P$. domesticus) in North America and with the migratory $P$. domesticus in Qinghai Province. Gen Comp Endocrinol 158:47-53

Liu X, Chen B (2000) Climatic warming in the Tibetan Plateau during recent decades. Int J Climatol 20:1729-1742

Lynn SE, Walker BG, Wingfield JC (2005) A phylogenetically controlled test of hypotheses for behavioral insensitivity to testosterone in birds. Horm Behav 47:170-177

Lyon B, Montgomerie B (1985) Incubation feeding in snow buntings: female manipulation or direct male parental care? Behav Ecol Sociobiol 17:279-284

Lyon B, Montgomerie R (1995) Snow bunting (Plectrophenax nivalis). In: Poole A (ed) The birds of North America Online. Cornell Lab of Ornithology, Ithaca. Retrieved from the Birds of North America Online: http://bna.birds.cornell.edu/bna/species/ 198. doi:10.2173/bna.198

McNamara JM, Houston AI (2009) Integrating function and mechanism. Trends Ecol Evol 24:670-675

Moe B, Stempniewicz L, Jakubas D, Angelier F, Chastel O, Dinessen F, Gabrielsen GW, Hanssen F, Karnovsky NJ, Rønning B, Welcker J, Wojczulanis-Jakubas K, Bech C (2009) Climate change and phenlogical responses of two seabird species breeding in the high arctic. Mar Ecol Prog Ser 393:235-246

Møller AP, Rubolini D, Lehikoinen E (2008) Populations of migratory bird species that did not show a phenological response to climate change are declining. Proc Nat Acad Sci USA 105: $16195-16200$

Moss S, deLeiris L (1988) Natural history of the Antarctic Peninsula. Columbia University Press, New York, p 208

Nisbet ICT (2000) Disturbance, habituation and management of waterbird colonies. Waterbirds 23:312-332 
Odling-Smee FJ (1988) Niche-constructing phenotypes. In: Plotkin HC (ed) The role of behavior in evolution. MIT Press, Cambridge, MA, pp 73-131

Parmesan C, Yohe G (2003) A globally coherent fingerprint of climate change impacts across natural systems. Nature 421:37-42

Pulido F, Berthold P, Mohr G, Querner U (2001) Hertiability of the timing of autumn migration in a natural bird population. Proc $\mathrm{R}$ Soc Lond B 268:1471-2954

Richardson MI, Moore IT, Soma KK, Lei FM, Wingfield JC (2003) How similar are high latitude and high altitude habitats? A review and a preliminary study of the adrenocortical response to stress in birds of the Qinghai-Tibetan plateau. Acta Zool Sin 49:1-19

Romero LM, Soma KK, O'Reilly KM, Suydam R, Wingfield JC (1998a) Hormones and territorial behavior during breeding in snow buntings Plectrophenax nivalis: an arctic-breeding songbird. Horm Behav 33:40-47

Romero LM, Soma KK, Wingfield JC (1998b) Changes in pituitary and adrenal sensitivities allow snow buntings (Plectrophenax nivalis) an arctic breeding song bird, to modulate corticosterone release seasonally. J Comp Physiol B 168:353-358

Silverin B, Wingfield JC, Stokkan K-A, Massa R, Järvinen A, Anderson NA, Lambrechts M, Sorace A, Blomqvist D (2008) Ambient temperature effects on photo-induced gonadal cycles and hormonal secretion patterns in great tits from three different breeding latitudes. Horm Behav 54:60-68

Smith AT, Foggin JM (1999) The plateau pika (Ochotona curzoniae) is a keystone species for biodiversity on the Tibetan plateau. Anim Conserv 2:235-240

Smith RD, Marquiss M (1995) Production costs of nesting attempts in snow buntings Plectrophenax nivalis: why do they attempt second broods? Ibis 137:469-476

Steegers-Theunissen RP, Obermann-Borst SA, Kremer D, Lindemans J, Siebel C, Steegers EA, Slagboom E, Heijmans BT (2009) Periconceptional maternal folic acid use of $400 \mathrm{ug}$ per day is related to increased methylation of the $I G F 2$ gene in the very young child. PLoS ONE 4:e7845

Stone RS, Dutton EG, Harris JM, Longenecker D (2001) The advancing date of spring snowmelt in the Alaskan Arctic. Proc. 11th Atmospheric Radiation Measurement (ARM) Science Team Meeting, March 19-23, 2001, Atlanta, Georgia

Stone RS, Dutton EG, Harris JM, Longenecker D (2002) Earlier spring snowmelt in northern Alaska as an indicator of climate change. J Geophys Res 107(D10), 4089. doi:10.1029/2000 JD000286

Thomas CD, Lennon JJ (1999) Birds extend their ranges northwards. Nature 399:213

Tinbergen N (1939) The behavior of the snow bunting in spring. Trans Linn Soc NY 5:1094

Travis JM (2003) Climate change and habitat destruction: a deadly anthropogenic cocktail. Proc R Soc Lond B 270:467-473

Visser ME (2008) Keeping up with a warming world; assessing the rate of adaptation to climate change. Proc R Soc Lond B 275:649-659

Visser ME, Holleman LJM (2001) Warmer springs disrupt the synchrony of oak and winter moth phenology. Proc R Soc Lond B 268:289-294

Visser ME, van Noordwijk AJ, Tinbergen JM, Lessells CM (1998) Warmer springs lead to mistimed reproduction in great tits (Parus major). Proc R Soc Lond B 265:1867-1870
Walker BG, Boersma PD, Wingfield JC (2005) Field endocrinology and conservation biology. Integr Comp Biol 45:12-18

Walther GR, Post E, Convey P, Menzel A, Parmesan C, Beebee TJC, Fromentin JM, Hoegh-Guldberg O, Bairlein F (2002) Ecological responses to recent climate change. Nature 416:389-395

Wang B, French HM (2006) Climate controls and high-altitude permafrost, Qinghai-Xizang (Tibet) Plateau, China. Permafrost Periglac Process 5:87-100

Wingfield JC (2003) Control of behavioral strategies for capricious environments. Anim Behav 66:807-816

Wingfield JC (2005) Flexibility in annual cycles of birds: implication for endocrine control mechanisms. J Ornithol 146:291-304

Wingfield JC (2008a) Comparative endocrinology, environment and global change. Gen Comp Endocrinol 157:207-216

Wingfield JC (2008b) Organization of vertebrate annual cycles: implications for control mechanisms. Philos Trans R Soc Lond B 363:425-441

Wingfield JC, Farner DS (1993) Endocrinology of reproduction in wild species. In: Farner DS, King JR, Parkes KC (eds) Avian biology, vol IX. Academic, New York, pp 164-327

Wingfield JC, Kenagy GJ (1991) Natural regulation of reproductive cycles. In: Schreibman M, Jones RE (eds) Vertebrate endocrinology: fundamentals, biomedical implications, vol 4, Part B. Academic, New York, pp 181-241

Wingfield JC, Ramenofsky M (1997) Corticosterone and facultative dispersal in response to unpredictable events. Ardea 85:155-166

Wingfield JC, Hahn TP, Levin R, Honey P (1992) Environmental predictability and control of gonadal cycles in birds. In: Grier $\mathrm{H}$, Cochran R (eds) Biology of the chordate testis. J Exp Zool 261:214-231

Wingfield JC, Suydam R, Hunt K (1994) Adrenocortical responses to stress in snow buntings and Lapland longspurs at Barrow, Alaska. Comp Biochem Physiol 108:299-306

Wingfield JC, Hahn TP, Wada M, Astheimer LB, Schoech S (1996) Interrelationship of day length and temperature on the control of gonadal development, body mass and fat depots in whitecrowned sparrows, Zonotrichia leucophrys gambelii. Gen Comp Endocrinol 101:242-255

Wingfield JC, Hahn TP, Wada M, Schoech S (1997) Effects of day length and temperature on gonadal development, body mass and fat depots in white-crowned sparrows, Zonotrichia leucophrys pugetensis. Gen Comp Endocrinol 107:44-62

Wingfield JC, Breuner C, Jacobs J, Lynn SE, Maney D, Ramenofsky M, Richardson R (1998) Ecological bases of hormone-behavior interactions: the "emergency life history stage". Am Zool 38:191-206

Wingfield JC, Hahn TP, Maney DL, Schoech SJ, Wada M, Morton ML (2003) Effects of temperature on photoperiodically-induced reproductive development, circulating plasma luteinizing hormone and thyroid hormones, body mass, fat deposition and molt in mountain white-crowned sparrows, Zonotrichia leucophrys oriantha. Gen Comp Endocrinol 131:143-158

Wu Q, Liu Y (2004) Ground temperature monitoring and its recent change in Qinhai-Tibet Plateau. Cold Reg Sci Technol 38:85-92

Wu S, Yin Y, Zheng D, Yang Q (2005) Climate changes in the Tibetan Plaeatu during the last three decades. Acta Geogr Sin 60:3-11

Zheng D, Li B (1999) Progress in studies on geographical environments of the Qinghai-Xizang Plateau. Chin Geogr Sci 9:289-296 